\title{
Dropped Out of School Prevention Through the Smart Indonesia Program
}

\author{
Syaiful Bahri* \\ Faculty of Teacher Training and Education, University of Bengkulu \\ *Corresponding author. E-mail: syaiful@iaincurup.ac.id
}

\begin{abstract}
The Smart Indonesia Program is one of the efforts of the Indonesia government in educating the nation's life, which is the preamble on 1945 Constitution and The National Education System Law in Indonesia. There are 4 objectives of the Smart Indonesia Program, consist; Overcoming financial difficulties of students in accessing educational service facilities; Anticipating the potential of students dropping out of school and motivating them to go back to study; Helping the parents of students who are low economic to fund the education of school-age children; Supporting and making the 9-year compulsory primary education a success. The Indonesian government has targeted who cannot pursue education on the grounds of being economically incapacitated, and no people who are illiterate and do not have a minimum equivalent of Junior high school. The symbol of the membership The Smart Indonesia Program assistance is a Card Smart Indonesia Program, the amount of The Smart Indonesia Program fund distribution has given every student that are: first, Elementary School equivalent of IDR 450.000 per year; secondly, Junior High School equivalent of IDR 750.000 per year; thirdly, Senior High School or vocational college equivalent of IDR 1.000 .000 per year; educational services at schools / Learning Activity Centers, Training Course Institutions is given a fund of Rp1.000.000. The Smart Indonesia Program has been effective from 2015 to 2019 amounted IDR 958,186,389,870,640.The technique of collecting data researcher used documents, research results that have relevance to the Smart Indonesia Programs' articles, and coverage in media data. The processing techniques of collecting data, researcher used documents, research result, technique data display and conclusion.
\end{abstract}

Keywords: Dropout out school, Smart Indonesia program, Primary school.

\section{INTRODUCTION}

Education is a long-term investment to create smart people by going through a long learning process. Meanwhile, the results will be enjoyed for a long time and there is not even a certain time limit even though the person concerned has passed away [1]. The created smart Indonesians are a mandate set out in the preamble of the 1945 Constitution in the fourth paragraph "to educate the nation's life". In carrying out the mandate to educate the nation's life, it is the government's obligation to facilitate the process and everything related to learning as stated in articles 31: 1 and 2 of the 1945 Constitution, paragraph 1 "Every citizen has the right to receive teaching. 2 The government strives and implements a national teaching system.

The implementation of national education in Indonesia is regulated through the National Education in Indonesia is regulated through National Education System, which states that; the principles of education as stated in article 4: 1, Ministry of Religion [2]: "Education is carried out in a democratic and just manner not discriminatory by upholding human rights, religious values, cultural values, and national diversity". Furthermore, the function of education as Article 3, Ministry of Religion: "National education has the function of developing capabilities and shaping the character and civilization of a nation with dignity to educate the nation's life, aiming at developing the potential of students to become faithful and obedient, healthy, knowledgeable, capable, creative, independent, and become democratic and responsible citizens.

Furthermore, national education in the Ministry of National Education [3] stated "Joint responsibility between local government and society". The amount of the 
national education budget as stipulated in Republic of Indonesia Law Number 20 of 2003 in article 49: 1, Ministry of Religion : "Education funds other than teacher salaries and official education costs are allocated minimum of $20 \%$ the Revenue Budget state expenditure for the education sector $20 \%$ Regional Budget and Expenditure Income.

Indonesian society is such diverse in various aspects such as; customs, livelihoods, geographic areas, level of knowledge of the students' parents, the effect on thinking patterns of both parents and students themselves, especially in some rural areas. So the impact on the interest and determination to gain knowledge is very weak. Based on the result there are not a few parents of students who don't care about their children's education so their children are doesn't goes to school, left school, and some parents who say school is for is just a waste of money, if you want get a lot of money you can farm like planting oil palm, and planting vegetables so on.

Parents' mindset described above, the effect is children uninterested to go to school, students stop out, students dropping out of school because of various cases as likes fighting, skipping school etc. Living in rural areas which are difficult to reach existing education units, it has managed by the government and community. The Republic Indonesia government has programmed the compulsory education of nine years of basic education, the program purpose is every citizen of the Republic of Indonesia has at least graduated from Junior High School, and free from illiteracy nationally.

The solution provided by the government to children who do not have a junior high school graduate certificate, the government gave a program's name is the Smart Indonesia Program, through Presidential tuition Regulation No.7 of 2014 concerning the Implementation of the Family Savings Program, Smart Indonesia Program and Healthy Indonesia Program [4][5].

The Smart Indonesia Program is one of government program's Indonesia Cabinet Volume I and Volume II as an implementation to educate the nation's life, both in terms of funding responsibilities, access to education, and educational facilities. This is purpose of the constitution Republic of Indonesia [6][7].

The Smart Indonesia Program government, has been effective from 2015 until now, but it doesn't know it because; first program carried out by President Joko Widodo, second is the target is only students whose parents incapable or poor, the third is the lack of socialization in the community, This is evidenced whose children didn't get smart Indonesia card, some parents' don't know they children actually get Indonesia Smart Program, less information by Indonesia government.

The Smart Indonesia Program Policy Regulation was established based on:

1. The Preamble 1945 Constitution of Republic Indonesia;

2. The Constitution 1945 of the Republic of Indonesia;

3. The Law of Republic of Indonesia Number 20 of 2003 concerning the National Education System;

4. The Law of Republic Indonesia Number 23 of 2014 concerning Regional Government;

5. The Government Regulation No. 48/2008 concerning Education support in money;

6. The Government Regulation No. 17/2010 concerning Management and Implementation of Education;

7. Presidential Regulation No. 166/2014 concerning the Program for the Acceleration of Poverty Reduction;

8. Presidential Decree No. 7 of 2014 concerning the implementation of the Program Saves Family Safety, and Indonesia Healthy Program;

9. Regulation of Indonesian Minister of Education Number 12 of 2015 concerning Smart Indonesia Program;

10. The Regulation between the Directorate General of major and Secondary Education, and Director General of Early Childhood Education Community Education Number: 07 / D / BP / 20176 Number: 02 / MPK.C / PM / 2017 concerning of Implementation Guidelines for Smart Indonesia Program.

\section{RESEARCH METHODS}

The method used descriptive qualitative method. The source of the data that the author found in writing this article use 
"secondary data in the form of data document from author" [8][9], journals that have relevance to the articles that the authors discuss. Through literature review, documents in the form of regulations are related to implementation of the Indonesia Smart Program. The technique of collecting data researcher used documents, research results that have relevance to the Smart Indonesia Programs' articles, and coverage in media data processing techniques of data reduction, data display and conclusion [10][11].

\section{DISCUSSION}

Education is the learning of knowledge, skills, and habits of a group of people that are passed down from one generation through teaching, training, or research. The meaning of education in Etymology comes from Latin educatum which is composed of two words are Eand Duco, E means development from the inside, while Duco it's mean the development. So notion etymologically of education is the process of developing one's own abilities and individual strengths [7].

According to Law No. 2 of 1989 , education is a conscious effort to prepare students through guidance; teaching, and training activities for in future. According to Law of Republic Indonesia Number 20 of 2003 concerned the national education system article 1 paragraph 1 "Education is a conscious and planned effort to create an atmosphere of learning and the learning process ideal participants actively develops their potential to have religious- spiritual strength, self-control, personality, intelligence, noble character, and skills needed society, nation and state " [1].

In general, everyone's thinking means that "being smart cannot be owned, but people who are smart because they are studies, a person who is smart because he is considered to have mastered in they are field. From this statement above, it means smart people need a process. They need to learn something first until they get learned full things. From process did, they get knowledge and being a smart people. Its mean smart people can be formed although from zero "(quote). Intelligence is a person's ability to motivate him, resilience in the face of failure, control emotions and delay satisfaction, and regulate mental states. Gregory stated that; intelligence is the ability or skill to solve problems or create valuable products in one or more specific cultural. Anita E. Wool folk stated that; intelligence is the ability to learn overall knowledge acquired, and the ability to adapt to new situations or environment.

The intelligence characteristics as follows: (1)Each of individual has the ability to improve and increase their intelligence; (2) Intelligence is not only can be changed, but can be taught to others too; (3) Intelligence is a multidimensional phenomenon resulting from interaction of the intellect and the brain; (4) Intelligence is a whole, complete in itself despite being multidirectional; (5) Each individual can become dominant in areas of the intelligence; (6) Various areas operate with each other, generally in harmony; (7) Many ways for every individual can be intelligent in each of area.

Meanwhile, the word genius "cannot be separated from a famous character is Einstein, a physicist, because Einstein said to be a genius, his name is known to many people until now? That's because he is a special person who is different from the others, where others only at the level smart or average, which makes different Einstein is thought to have "(quote).

Based on the opinions above definition of program notion education and the notions of smart, it shows that education is a conscious and programmed to create maturity through learning process.

Education is a long-term investment regardless of age, because it will be beneficial not only person concerned still alive, but also person passed away. Therefore, how important to be educated person because with education, then someone become an adult, not only mature in mental maturity but also mature in the sense of being smart, intelligent, and capable in their field.

The Smart Indonesia Program is a program carried out by the government of the Advanced Indonesia Cabinet Volume I and II which has been effective from 2015 to 2020. The implementation technique through regulation minister national education number 12 on 2015 concerning the Indonesia Smart community, who try to 
develop their potential learning process in available on certain pathways and types of education.

Through a symbol of the Indonesia Smart Card, it has a card given to a child from a family Social Protection Card, as an identity to benefit from the Indonesia Smart Program, and also who are committed to the advancement and interests of both formal and non-formal education[12][13].

The Indonesia Smart Program is a cash assistance program from government gave to students whose parents unable to pay for their children's education, and poor families. As a continuation and expansion of the target of the poor student assistance program had been running in previous years.

The advantages from The Smart Indonesia Program consist ; Firstly, improve access for children ages 6 to 21 years to get education up to graduate junior high school or nine years of education; second, prevent students from dropping out of school or not continue their education in lower economic; and the last is attracting students dropping out of school or not continue from primary school to junior high school and equivalent that return to educational services at schools / Learning Activity Centers, Training Course Institutions, Non-formal Education Units, and Vocational Training Centers.

Based on the purpose and benefit from the Smart Indonesia Program above, if we continue of the Poor Students Aid, It can be seen that Smart Indonesia Program has a wider than poor assistance students than formal schools as students level in elementary school, junior high school, high school and vocational college, but the Smart Indonesia Program is wider, not only formal education but also non-formal education (National School Equivalency) such as; participants in Package A, Package B, Package C, Education \& Training Center, Language College, and Training Centers. This means is the Smart Indonesia Program was such beneficial because it touches all educational units, both formal and nonformal, as an excellent program government to improve education the nation's life.

The target and amount funds for the Smart Indonesia Program based on the Ministry of Religion the Republic of Indonesia number 12 on 2015 are children aged 6 to 21 years with the following criteria consist; First, students of Social Protection Family Card holders/Card Family Welfare; second, students participants program Family's Hope; Third, the status of orphans children, social homes/orphanages; Fourth, students who do not attend school (drop out) is expected to return to study at school; five is students who are affected by the economic impact of natural disasters; the last is students who is threatened with dropping out of school [14].

Meanwhile, the amount of the Smart Indonesia Program Fund Distribution has given every student that are: first, Elementary School / Package A equivalent of IDR 450,000 per year; secondly, Junior High School/ Package B equivalent of IDR 750.000 per year; thirdly, Senior High School or vocational college Packet C equivalent of IDR 1,000,000 per year; furthermore, educational services at schools / Learning Activity Centers, Training Course Institutions is given a fund of Rp1,000,000 for participating in standardized courses and training in one-course period without considering the length of the course.

\section{CONCLUSION}

Based on the facts described above, The Smart Indonesia Program is a continue of the previous Poor Student Assistance program with a wide target not only in formal education units but also to nonformal education units, even some courses to reduce the number of students who drop out of school; The benefits of implementing the Smart Indonesia Program are very strong and their existence is so beneficial; The target criteria and the number of funds in the Smart Indonesia Program are clear, measurable, targeted, effective even though the disbursement of funds is quite late than the schedule.

\section{REFERENCES}

[1] National Education Standards, PP RI Number 19 of 2005 The concerning National Education Standards Equipped with explanations.

[2] The Ministry of Religion of the Republic of Indonesia, 2006, Law Number 14 of 2005 concerning Teachers and Lecturers and Law of the Republic of Indonesia Number 20 of 
2003 concerning the National Education System, Jakarta.

[3] National Education, Ministry, 2008, The Government Regulation of the Republic of Indonesia Number 48 Year 2008 concerning Education Funding.

[4] Ngiode Syafrin, Erwinsyah Alfian, 2020, The Effectiveness of Smart Indonesian Programs in Gorontalo District Madrasas, Al-Tanzim Journal of Islamic Education Management Journal, Vol. 04 No. 01, accessed October 13, 2020.

[5] The Regulation of the minister of national education, Number 12 of 2015 The concerning Smart Indonesia Program; Education, and Culture, Ministry, Joint Regulation between the Directorate General of Primary and Secondary Education and the Director General of Early Childhood Education and Community Education Number: 07 / D / BP / 2017 Number: 02 / MPK.C / PM / 2017 Concerning the Implementation Guidelines for the Smart Indonesia Program 2017.

[6] Setiandika Verto, 2017, The Evaluation of the Implementation of the Distribution of the Smart Indonesia Program (PIP) for Underprivileged Students (Study at SDN JrebengWetan 2016), Journal of Pedagogy Vol. 04 No. 01, accessed October 15, 2020.

[7] Sri Maya Ismayani et al, 2019, The Implementation of Smart Indonesia Program (PIP), PLS Scientific Cendikiawan Journal Vol. 4 No. 1, accessed October 15, 2020.

[8] Sugiyono, 2015, The Educational Research Methods with Quantitative Approaches, Qualitative and R \& D, Bandung, Alfabeta.

[9] Emzir, 2015, Quantitative \& Qualitative Education Research Methodology, Collerational Experiment Ex Post Facto Ethnography Grounded Theory Action Research, Jakarta, PT. Rajagrafindo.

[10] Mulyatiningsih, Endang, 2013, Applied Research Methods in Education, Jakarta, Alfabeta.

[11] Riduwan, 2009, Metode dan Teknik Penyusunan Proposal Penelitian, Bandung, Alfabeta.
[12] Sulthan Muhammad, Sasongko Totok, 2017, The Implementation of Poverty Reduction Program Policies through Social Security Cards and Smart Indonesia Cards in Communities (Case Study in Kauman Kelurahan, Malang City), Journal of Social and Political Sciences ISSN. 2442-6962 Vol. 6 No. 1 www.publikasi.unitri.ac.id accessed October 12, 2020.

[13] Ainun Farida Nikmah et al, 2020, Did the Smart Indonesia Card Succeed in Reducing the Dropout Rate, Journal of Educational Communication Vol. 4 No. 2, 2020, P-ISSN 2549-1725 EISSN 2549-4163, accessed October 14, 2020.

[14] Simanjuntak, A. P., Rusdarti, R., \& Prasetyo, P. E., 2019, The Implementation of Hope Family Program (PKH) in Poverty Prevention Effort in Kluwut Village Bulakamba District Brebes Regency. Journal of Economic Education, 8(1), 12-21. 